\title{
TLR2 and TLR4 Polymorphisms Are Not Associated with Acne Vulgaris
}

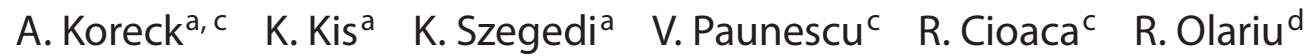 \\ S. Negruc $\quad$ Z. Bata-Csorgo ${ }^{a, b} \quad$ L. Kemeny ${ }^{a, b} \quad$ A. Dobozy ${ }^{a, b} \quad$ M. Szell ${ }^{b}$ \\ ${ }^{a}$ Department of Dermatology and Allergology, University of Szeged, and b Dermatological Research Group of the \\ Hungarian Academy of Sciences, Szeged, Hungary; Departments of CImmunology and dParasitology, \\ Victor Babes University of Medicine and Pharmacy, Timisoara, Romania
}

\section{Key Words}

Acne vulgaris $\cdot$ Toll-like receptors $\cdot$ Single-nucleotide polymorphism

Acne vulgaris is a chronic inflammatory disease of the pilosebaceous unit affecting most teenagers and numerous adults. For most patients, acne is limited to occasional flares of comedones and pustules; however in severe cases, host inflammatory response can result in painful nodules and disfiguring scars. Acne is a multifactorial disease; traditional etiological factors include increased sebum production, ductal hyperkeratosis, colonization with Propionibacterium acnes and production of inflammatory mediators, but, according to twin studies, genetic factors also contribute to the development of the symptoms [1-4].

In the case of multifactorial diseases, the presence of several predisposing gene alterations assists the environmental factors in eliciting the symptoms. Up to now only a few suspected genes have been investigated in connection with acne susceptibility [5-8]. Toll-like receptors (TLRs) are expressed on the surface of several immune cells, and they are responsible for the recognition of mi-

A.K. and K.K. contributed equally to this work.

\section{KARGER}

Fax +4161306 1234

E-Mail karger@karger.ch

www.karger.com
(C) 2006 S. Karger AG, Basel

$1018-8665 / 06 / 2133-0267 \$ 23.50 / 0$

Accessible online at:

www.karger.com/drm crobial molecular patterns. Since TLR2 and TLR4 affect immune processes, they may play a role in the pathogenesis of acne. TLR2 and TLR4 expression was found to be increased in the epidermis of acne lesions in vivo [9]; furthermore, TLR2 was expressed on the cell surface of macrophages surrounding pilosebaceous follicles, and $P$. acnes induced the cytokine production of monocytes through a TLR2-dependent pathway [10].

Here we have investigated two mutations of the TLR2 gene (C2179T in the NM_003264.2 sequence and rs5743708 causing the amino acid changes Arg677Trp and Arg753Gln, respectively) as well as two polymorphisms of the TLR4 gene (rs4986790 and rs4986791 causing the amino acid changes Asp299Gly and Thr399Ile, respectively) in 101 Caucasian subjects, 63 with acne vulgaris and 38 healthy controls. These polymorphisms have been suggested to be associated with several infectious diseases [11]. Acne vulgaris diagnosis was defined as a physician's diagnosis. Acne patients were subclassified into three groups, as having severe symptoms (acne conglobata group, $\mathrm{n}=17$ ), medium symptoms (acne papulopustulosa group, $\mathrm{n}=39$ ) and mild symptoms (acne comedonica group, $\mathrm{n}=7$ ). The control group comprised patients showing no symptoms of acne during their life.

We isolated genomic DNA from whole blood obtained from the study subjects, using the Perfect gDNA Blood Mini Isolation Kit (Eppendorf AG, Hamburg, Germany)

Andrea Koreck, MD, $\mathrm{PhD}$

Department of Dermatology and Allergology

University of Szeged, PO Box 427, HU-6701 Szeged (Hungary)

Tel. +36 62545 799, Fax +36 62545954

E-Mail koreck@mail.derma.szote.u-szeged.hu 
Table 1. Allele frequencies of the observed polymorphisms (rs4986790 and rs4986791) in the TLR4 gene causing the amino acid changes Asp299Gly and Thr399Ile, respectively

\begin{tabular}{llll}
\hline & Acne vulgaris $(\mathrm{n}=63)$ & Control $(\mathrm{n}=38)$ & $\mathrm{USA}^{1}(\mathrm{n}=47)$ \\
\hline \multicolumn{2}{l}{ TLR4 } & Asp299Gly \\
$\mathrm{A} \quad 0.952$ & 0.934 & 0.904 \\
$\mathrm{G} \quad 0.048$ & 0.066 & 0.096 \\
\hline \multicolumn{2}{l}{ TLR4 } & Thr399Ile \\
$\mathrm{C}$ & 0.952 & \\
$\mathrm{~T}$ & 0.048 & 0.934 & 0.947 \\
\end{tabular}

${ }^{1}$ From the database of the IIPGA, www.innateimmunity.net.

and the Generation Capture Column Kit (Gentra Systems Inc., Minneapolis, Minn., USA) according to the manufacturer's instructions. Informed consent was obtained from each individual before sample collection, and the study was conducted according to the Helsinki Declarations. Primer sets were designed by Primer 3 software at http://frodo.wi.mit.edu/cgi-bin/primer3 such that products did not exceed $300 \mathrm{bp}$ and synthesized by the Oligonucleotide Laboratory, Biological Research Center of the Hungarian Academy of Sciences (Szeged, Hungary). PCR was performed in a total volume of $50 \mu \mathrm{l}$ containing $200 \mathrm{ng}$ of template DNA, $1-1 \mu \mathrm{l}$ of $10 \mathrm{pmol} / \mu \mathrm{l}$ primers and $25 \mu$ l REDTaq ReadyMix PCR Reaction Mix (Sigma-Aldrich Co., St. Louis, Mo., USA). The cycling profile involved denaturation at $95^{\circ} \mathrm{C}$ for $30 \mathrm{~s}$, annealing at $57^{\circ} \mathrm{C}$ for $30 \mathrm{~s}$ and extension at $72^{\circ} \mathrm{C}$ for $1 \mathrm{~min}$ for 40 cycles. Final extension was continued at $72^{\circ} \mathrm{C}$ for $10 \mathrm{~min}$. The amplification was carried out in a MyCycler Thermal System (Bio-Rad, Hercules, Calif., USA). PCR products were purified by Quantum Prep PCR Kleen Spin Columns (Bio-Rad) according to the manufacturer's instructions. The alleles of TLRs were confirmed by sequencing (Agricultural Biotechnology Center, Godollo, Hungary) and analyzed by the Bio Edit program (Ibis Therapeutics, Carlsbad, Calif., USA). Statistical analysis was performed at the statistical homepage faculty.vassar. edu/lowry/VassarStats.html. Allele frequency data were compared using Fisher's exact probability test; a p value less than 0.05 was considered significant.

Allele frequencies of the studied single-nucleotide polymorphisms of the TLR4 gene causing the amino acid changes Asp299Gly and Thr399Ile in the acne vulgaris and control group are shown in table 1 . The two studied polymorphisms of the TLR4 gene occurred simultane-
Table 2. Allele frequencies of the observed mutations (C2179T in the NM_003264.2 sequence and rs5743708) in the TLR2 gene causing the amino acid changes Arg677Trp and Arg753Gln, respectively

\begin{tabular}{|c|c|c|c|}
\hline & Acne vulgaris $(n=63)$ & Control $(\mathrm{n}=38)$ & $\mathrm{USA}^{1}(\mathrm{n}=89)$ \\
\hline \multicolumn{4}{|c|}{ TLR2 Arg677Trp } \\
\hline & SNP not detected & SNP not detected & \\
\hline \multicolumn{4}{|c|}{ TLR2 Arg753Gln } \\
\hline G & SNP not detected & SNP not detected & 0.977 \\
\hline $\mathrm{A}$ & SNP not detected & SNP not detected & 0.023 \\
\hline
\end{tabular}

${ }^{1}$ From the database of the IIPGA, www.innateimmunity.net.

ously $(\mathrm{n}=11)$ composing a haplotype. Furthermore, the individuals carrying these alleles were all heterozygotes for both TLR4 single-nucleotide polymorphisms in our study population. These findings correspond with the data in the literature $[12,13]$. There were no statistical differences in the prevalence of these two polymorphisms between the control and acne vulgaris groups, even if the acne vulgaris group was divided into subclasses according to the severity of symptoms. The frequencies of the observed alleles were in good agreement with data from the database of the National Heart, Lung and Blood Institute, Programs for Genomic Applications (IIPGA, www.innateimmunity.net).

The studied mutations of the TLR2 gene were not detected in our study population (table 2). The mutation causing the Arg753Gln amino acid change has a low prevalence according to the databases as well. Furthermore, at the time we had completed the sequencing of our samples, Malhotra et al. [14] demonstrated that the mutation causing the Arg677Trp change, which had been published in 2001 [15], was not a true polymorphism, but a sequencing error.

Our recent data have shown that certain $P$. acnes strains are capable of activating the innate immune responses in keratinocytes, and this induction is TLR2 and TLR4 dependent [16]. Beside keratinocytes, sebocytes and professional immune cells, e.g. macrophages, also express TLRs, through which $P$. acnes can contribute to inflammation at the site of acne lesions $[10,17]$. Although the polymorphisms and mutations of TLR 2 and TLR4 genes could be hypothesized to contribute to the pathogenesis of acne, the single-nucleotide polymorphisms studied here were not proved to assist in the development of acne. The fact that this study could not find any asso- 
ciations between acne and the studied TLR2 and TLR4 polymorphisms does not exclude the possibility that other polymorphisms of these genes would contribute to acne pathogenesis. Further studies are needed to decide whether additional TLR2 and TLR4 polymorphisms are associated with acne and/or the reported upregulation of these genes in acne [9] is the result of upstream regulatory events.

\section{Acknowledgements}

This work was supported by the grants GVOP-3.1.1-2004-050104/3.0, GVOP-3.2.1-2004-04-0372/3.0, GVOP-3.2.2-2004-070010/3.0 (European Union Economic Competitiveness Operational Programme), NKFP1-00004/2005 (National Research and Development Programmes of the Szechenyi Plan), ETT 425/2003 (Hungarian Ministry of Health) and CEEX 29/2005 (Romanian Ministry of Education and Research).

\section{References}

1 Zouboulis CC, Eady A, Philpott M, Goldsmith LA, Orfanos C, Cunliffe WC, Rosenfield R: What is the pathogenesis of acne? Exp Dermatol 2005;14:143-152.

2 Koreck A, Pivarcsi A, Dobozy A, Kemeny L: The role of innate immunity in the pathogenesis of acne. Dermatology 2003;206:96105.

3 Oberemok SS, Shalita AR: Acne vulgaris. I. Pathogenesis and diagnosis. Cutis 2002;70: 101-105.

4 Evans DM, Kirk KM, Nyholt DR, Novac C, Martin NG: Teenage acne is influenced by genetic factors. Br J Dermatol 2005; 152:579581.

5 Ostlere LS, Rumsby G, Holownia P, Jacobs HS, Rustin MH, Honour JW: Carrier status for steroid 21-hydroxylase deficiency is only one factor in the variable phenotype of acne. Clin Endocrinol (Oxf) 1998;48:209-215.

6 Sawaya ME, Shalita AR: Androgen receptor polymorphisms (CAG repeat lengths) in androgenetic alopecia, hirsutism, and acne. J Cutan Med Surg 1998;3:9-15.
7 Paraskevaidis A, Drakoulis N, Roots I, Orfanos CE, Zouboulis CC: Polymorphisms in the human cytochrome P-450 1A1 gene (CYP1A1) as a factor for developing acne. Dermatology 1998;196:171-175.

8 Ando I, Kukita A, Soma G, Hino H: A large number of tandem repeats in the polymorphic epithelial mucin gene is associated with severe acne. J Dermatol 1998;25:150-152.

9 Jugeau S, Tenaud I, Knol AC, Jarrousse V, Quereux G, Khammari A, Dreno B: Induction of toll-like receptors by Propionibacterium acnes. Br J Dermatol 2005;153:11051113.

10 Kim J, Ochoa MT, Krutzik SR, Takeuchi O, Uematsu S, Legaspi AJ, Brightbill HD, Holland D, Cunliffe WJ, Akira S, Sieling PA, Godowski PJ, Modlin RL: Activation of toll-like receptor 2 in acne triggers inflammatory cytokine responses. J Immunol 2002;169:15351541.

11 Schroder NW, Schumann RR: Single nucleotide polymorphisms of Toll-like receptors and susceptibility to infectious disease. Lancet Infect Dis 2005;5:156-164.

12 Arbour NC, Lorenz E, Schutte BC, Zabner J, Kline JN, Jones M, Frees K, Watt JL, Schwartz DA: TLR4 mutations are associated with endotoxin hyporesponsiveness in humans. Nat Genet 2000;25:187-191.
13 Schippers EF, van't Veer C, van Voorden S, Martina CA, le Cessie S, van Dissel JT: TNFalpha promoter, Nod2 and toll-like receptor4 polymorphisms and the in vivo and ex vivo response to endotoxin. Cytokine 2004;26: 16-24.

14 Malhotra D, Relhan V, Reddy BS, Bamezai R: TLR2 Arg677Trp polymorphism in leprosy: revisited. Hum Genet 2005;116:413-415.

15 Kang TJ, Chae GT: Detection of Toll-like receptor 2 (TLR2) mutation in the lepromatous leprosy patients. FEMS Immunol Med Microbiol 2001;31:53-58.

16 Nagy I, Pivarcsi A, Koreck A, Szell M, Urban E, Kemeny L: Distinct strains of Propionibacterium acnes induce selective human beta-defensin- 2 and interleukin- 8 expression in human keratinocytes through tolllike receptors. J Invest Dermatol 2005;124: 931-938.

17 Kim J: Review of the innate immune response in acne vulgaris: activation of Tolllike receptor 2 in acne triggers inflammatory cytokine responses. Dermatology 2005;211: 193-198. 